\title{
Where has all the youth crime gone? Youth justice in an age of austerity
}

Youth justice under the Coalition government in England and Wales has been characterised by considerable gains - falling youth crime, increased diversion and substantial reductions in child imprisonment - that would generally be associated with a progressive agenda. Focusing on youth justice policy in England and Wales, this article suggests that the tensions implicit in a government of the new right delivering outcomes that demonstrate an increased tolerance to children who offend, can be explained by the logic of austerity. That same logic brings with it other policy measures that are potentially less compatible with children's wellbeing.

\section{The youth crime of today is not what it used to be}

Youth crime in England and Wales under the UK Coalition government is not what it was, in at least two senses. First, there is significantly less of it. In 2012, 47,019 children below the age of 18 years received a formal pre-court disposal ${ }^{1}$ or conviction for an indictable offence compared with 73,712 in 2010 when the new administration came to power, a decline of almost 36\% (Ministry of Justice, 2013). ${ }^{2}$

Second, youth crime is no longer the 'hot' political issue that it once was. From the early 1990s to the mid-2000s, youth justice constituted the locus of what has been referred to as a 'partisan 'arms race" (Centre for Social Justice, 2012:26) wherein the main political parties vied to demonstrate their tough credentials to the electorate (Pitts, 2003). This 'punitive turn' is generally understood as a manifestation of an internationally changed orientation towards crime and offenders whose origins lie, over the longer term, in social and economic changes associated with late modernity (Garland, 2001). There were, of course, significant differences between adult justice systems and those that deal with children, and between the UK and other Western jurisdictions, but while it stood in the vanguard, England and Wales thus not totally exceptional in this regard, although direct policy transfer was more likely with the United States than with European neighbours (Muncie, 2008).

New Labour's engagement in this process was an enthusiastic one: during the 1997 election campaign, one of the party's 'five pledges' to the public was to ensure swifter punishment for

\footnotetext{
${ }^{1}$ Formal pre-court disposals comprise: reprimands, final warnings, youth cautions and youth conditional cautions

${ }^{2}$ Although the focus of this article is England and Wales, youth crime has also fallen sharply in many other Western jurisdictions for reasons that are not entirely understood
} 
persistent young offenders (Smith, 2014). However, as the 2010 election loomed, law and order was supplanted by the economy as the foremost political priority (Downes and Morgan, 2012). While both main parties' manifestos contained a chapter on crime, the focus on youth offending was considerably less marked than in the three previous elections and what discussion did appear was less punitive in tone. Labour's main concern was to ensure an expansion in leisure facilities for children in high crime areas and to promote neighbourhood policing; the Tories' sole reference to youth offending was to confirm that market mechanisms proposed for other areas of criminal justice provision, and the public sector more broadly, would apply equally to youth justice (Bateman, 2012).

New Labour's appeal to populist sentiment had been predicated on using the formal mechanisms of the youth justice system - and associated measures such as the anti-social behaviour order - to 'nip offending in the bud' (Home Office, 1997: paragraph 5.15) This emphasis on early intervention led to the criminalisation of large numbers of increasingly younger children (Goldson, 2000). One leading commentator's assessment of New Labour's youth justice legacy, published shortly after the Coalition took office, concluded that:

'In terms of its readiness to incarcerate children, England now comprises one of the most punitive youth justice sites in the western world (Goldson, 2010:170).

By contrast, the Coalition approach is set out in three high level targets whose logic would appear to be diversionary, aiming to keep children out of the system and out of custody:

- 'Reducing the number of first time entrants to the youth justice system; ${ }^{3}$

- reducing reoffending; and

- reducing custody numbers' (Ministry of Justice, 2010: paragraph 263).

Given the previous record, the introduction of a performance measure that sought to reduce child imprisonment was accordingly of some import and yielded practical consequences. In May 2010, the month of the election, 2,541 children were detained in the secure estate for children and young people; by February 2014, there were fewer than half that number $(1,183)$ (Ministry of Justice, 2014a).

Youth justice policy, it would appear, has shifted under the Coalition government. Moreover, at least some elements of that shift would seem to be in a progressive direction. If that characterisation is

\footnotetext{
${ }^{3} \mathrm{~A}$ first time entrant is a child with no previous criminal justice sanctions who receives a formal youth justice disposal
} 
broadly accurate, it might be thought in need of explanation since other areas of contemporary policy towards children has not displayed such progressive intent (Ridge, 2013).

\section{Continuity and change}

One consideration is the extent to which the policy is genuinely new. Certainly the incoming administration was keen to dissociate itself from its predecessor's approach, claiming that it would initiate 'a fundamental break with the failed and expensive policies of the past' (Ministry of Justice, 2010: 2). In some respects, this is unsurprising, since that is what politicians do. New Labour had also staked a claim to originality in 1997 when it contended that its programme sought to 'draw a line under the past and [set] out a new approach to tackling youth crime' (Home Office, 1997: preface). It is important to disentangle differences of substance from political flourish. Youth justice history in fact demonstrates threads of continuity interwoven with markers of change.

A distinct Coalition youth justice policy can be discerned, but there is also considerable overlap with what went before. The reforms encapsulated in New Labour's Crime and Disorder Act 1998 (CDA) comprised largely 'of measures that the previous Conservative administration would have found familiar and congenial' (Smith, 2003:228). They tended to reinforce what has been called the 'punitive turn' in youth justice which had originated several years earlier under a Conservative government (Muncie, 2008). It reflected an increased intolerance to children in conflict with the law manifested in: a process of 'netwidening' (expanding the youth justice net to incorporate behaviour that would not previously have attracted a formal sanction) (Cohen, 1985); reduced diversion from court; more intrusive and intensive community-based penalties, and an expanding use of child imprisonment (Goldson, 2002). So too, the origins of the policy changes outlined above pre-date the formation of the Coalition.

Much of the recent fall in youth crime can be attributed to a reduction in first time entrants (FTEs) in accordance with the first of the government's three targets for youth justice. In fact this indicator was adopted by New Labour in its 2008 Youth Crime Action Plan (Home Office, 2008) and the number of FTEs fell sharply thereafter. Youth crime thus began its downward trajectory two years before the change of administration (Bateman, 2013a). In addition, to being a diversionary measure which channelled literally thousands of children away from the expensive formal criminal justice system, Labour's FTE target reflected an emerging de-politicisation of youth crime. It could be read 'as intimating that harsh responses for children who broke the law were no longer de rigueur' 
(Bateman, 2012:45) and raised questions as to whether it was any longer appropriate to portray youth justice in England and Wales as characterised by an unrelenting 'punitivism' (Goldson, 2002).

Similarly, the child custodial population, which had risen inexorably during the 1990 s and remained stubbornly high for much of the subsequent decade, began to contract rapidly in 2008 (Allen, 2011) further testimony to the more tolerant climate emerging towards children who broke the law. The introduction of the Coalition target to reduce custody thus acted to confirm an existing trend rather than initiate it. The seeds of the progressive dynamics of current youth justice policy were sown well before the election.

\section{Detected youth offending and youth justice policy: a complex interrelation}

So far as it is possible to tell ${ }^{4}$, youth crime has been falling, with some fluctuation, since at least the early 1990s. In 2012, the number of children receiving a substantive disposal was $67 \%$ lower than in 1992 (Bateman, 2013a). The Coalition cannot accordingly claim sole credit for that trend.

Detected offending inevitably understates the extent of children's lawbreaking because the majority of crimes are not reported to the police or remain unsolved (McGuire, 2012). But there is a further complication. Policy change has a considerable influence on the treatment of children in trouble and impacts the degree to which they are drawn into the youth justice system or diverted from it.

Patterns of detected offending may not therefore mirror changes in young people's criminal activity. Equally, perceptions of the prevalence of youth crime - largely derived from official data - can affect youth justice policy. This complex interplay helps to explain recent patterns in detected youth crime while shedding further light on the roots of present policy trajectory.

Three features of the trend data stand out. First, the long-term pattern is one of decline from at least the early 1990s. Since this is largely consistent with what is known about crime more generally, one might reasonably infer that it represents a genuine reduction in children's offending over that period (Bateman, 2013a). The fall in crime - including youth crime - is an international phenomenon that is not fully understood, but in England and Wales at least has been accompanied by reductions among young people in use of drugs and alcohol (Marlow, 2014). Second, the period 2003 to 2007 saw a marked departure from this longer-term tendency in the form of a rapid, though short-lived,

\footnotetext{
${ }^{4}$ The most widely cited measures of crime - the Crime Survey for England and Wales and police recorded crime - cannot give a direct indication of youth offending, since the age of the perpetrator is not known unless he or she is apprehended. As a consequence, our knowledge of youth crime is limited largely to those offences that are detected (Bateman, 2014 forthcoming).
} 
rise in youth offending of more than $20 \%$. Finally, from 2008 onwards youth crime has again reduced, but at a rate that is significantly more pronounced than at any time in the past 20 years - a fall of almost 55\% in that period (Ministry of Justice, 2013). Given their striking nature, it seems unlikely that shifts in children's criminal behaviour could account for these departures from the underlying trend. A more plausible explanation points to shifts in youth justice policy, reflected in two government targets that encouraged extensive netwidening in the first instance and promoted informal responses to youth infractions of the law in the second.

In 2002, the government established a target to narrow the gap between offences recorded by the police and those 'brought to justice'. The indicator required a growth in the number of formal criminal justice sanctions imposed annually of almost quarter of million by March 2008 against a March 2002 baseline (Home Office, 2007). Although the measure did not apply specifically to children, they were disproportionately affected. The target was achieved - a year early - largely by criminalising behaviour that would previously have been dealt with informally; children - who typically have fewer contacts with the justice system and engage in less serious offending - were more likely than adults to have benefited from such informal responses which increasingly fell into abeyance (Nacro, 2008). The impact of netwidening was thus correspondingly greater for the younger group: between 2003 and 2007, the number of adults entering the criminal justice system rose by less than $1 \%$, the equivalent figure for those below the age of 18 years was $22 \%$ (Bateman, 2013a).

The 2002 target was criticised for diverting police resources from more serious crime to deal with petty transgressions (Flanegan, 2008) and for criminalising children (Nacro, 2008). While the underlying logic was consistent with New Labour's tough law and order pretensions, the artificially stimulated rise in detected youth crime led to something of a moral panic, with headlines warning of a wave of violent youth offending (see for instance, Leapman, 2008). More pragmatically, youth offending teams, courts and custodial institutions were overwhelmed by the sudden influx of children to the system, coincidentally just as the financial crisis hit the UK economy (Pitts and Bateman, 2010). An interventionist youth justice represented an expense that sat unhappily with new financial imperatives.

The target was replaced by a performance measure with the opposite impetus and the potential to cut costs. The Youth Crime Action Plan (Home Office, 2008) pledged to reduce the number of FTEs by $20 \%$ by 2020 , a reduction that was actually realised within 12 months. Equivalent annual reductions 
followed and the Coalition's adoption of the target ensured that the change of administration did not interrupt the diversionary dynamic.

\section{Pragmatic diversion and decarceration}

The policy volte face was thus less a principled rediscovery of the (well-evidenced) merits of diversion (McAra and McVie, 2007) and more a pragmatic response to changed financial circumstances (Creaney and Smith, 2014). Nonetheless the new target to reduce the number of FTEs required the development of a range of informal pre-court mechanisms that were not captured in the crime statistics but provided alternative avenues for dealing with children who might otherwise become FTEs. Such mechanisms included police administered 'community resolutions', 'triage' arrangements whereby referral to appropriate services is accompanied by 'no further action', and liaison and diversion schemes which seek to divert children with mental health difficulties and other associated vulnerabilities, to more suitable provision (Hart, 2014).

Such alternatives implied considerable relaxation (albeit not explicitly acknowledged by the government at the time) of the pre-court system introduced by the CDA 1998 which had provided for a rigid, tiered approach, whereby prosecution was mandated for the third offence at latest. For example, guidance had noted that informal action 'should be taken only in exceptional circumstances' (Home Office, 2002:8). From 2008, practice was increasingly no longer inhibited by such proscription (Criminal Justice Joint Inspection, 2012). The government's abolition of the final warning scheme and its replacement by a more flexible system of youth cautions through the Legal Aid, Sentencing and Punishment of Offenders Act 2012 (LASPOA) can accordingly be understood as formalising changes that had already occurred organically.

Similar considerations explain the decline in youth incarceration. There is compelling empirical evidence that increased diversion from prosecution is associated with lower rates of child imprisonment (Bateman, 2012). Delaying entry into the court system extends the number of options available to a child before custody appears inevitable, while simultaneously reducing the appearance of persistence which frequently triggers deprivation of liberty (Jacobson et al, 2010). Reduced imprisonment was accordingly a natural concomitant of the FTE target and other diversionary initiatives.

But locking up children is one of the more costly elements of the youth justice apparatus: in 2008, the purchase of secure accommodation accounted for two-thirds of the Youth Justice Board's total 
programme expenditure (Youth Justice Board, 2009). The constrained economic climate necessitated a policy reorientation to maximise the deflationary impact of diversion on the custodial population. This reorientation was expressed most concretely in legislative form: the Criminal Justice and Immigration Act 2008 introduced two statutory alternatives to custody - intensive supervision and surveillance and intensive fostering - and required courts imposing a sentence of detention to state why one of these alternatives could not be justified (Nacro, 2010). The Coalition's target to reduce child imprisonment was, in effect, reaffirming existing policy designed to elicit savings to the hard-pressed exchequer. To address the fact that custodial sentences had fallen faster than remands, LASPOA contained provision that restricted the circumstances in which children could be remanded to custody, leading to further reductions in the remand population (Hart, 2012).

\section{Echoes of Thatcher?}

While there are differences, the current period is redolent of an earlier one in important respects. Margaret Thatcher's administration was not known for its tolerance; indeed Pitts (1988:40) notes that it gloried in the 'rise of vindictiveness'. Yet during the 1980 s, child imprisonment fell by $80 \%$ as the use of diversionary measures expanded: pre-court measures accounted for less than half of all disposals in 1980 but more than three quarters in 1990 (Allen, 1991). These developments reflected a conscious depoliticisation of youth justice (Smith, 2014).

It has been persuasively argued that this progressive moment was made possible by a tension at the heart of the Thatcherite project: a government committed to being tough on crime was also wedded to a reduction in state expenditure. Reduced tax revenue and an increased burden of benefit payments - both consequences of rising unemployment - triggered a search for areas where costs could be scaled back (Pitts, 1988). The youth justice system offered one such area that carried minimum political risk. The Coalition's approach accordingly has an historical pedigree; it also displays tensions comparable to the Thatcher period. While the focus hitherto has been on the progressive aspects of contemporary youth justice policy, austerity inevitably comes with a price.

\section{The price of everything: prospects for children in conflict with the law}

If the commitment to diversion and decarceration is largely explicable as crude economic calculation, then those gains may, in the coming period, be vulnerable to pragmatic reversal if political considerations dictate that they are no longer tenable. The Crime and Justice Act 2014, for instance, contains provision to limit diversion for adults by proscribing cautions, other than in exceptional circumstances, for more serious offences or where the individual commits a similar - 
less serious - offence within two years. An equivalent clampdown on diversion for children cannot be ruled out if being soft on youth crime comes to be seen as an electoral liability at some point in the future.

More immediately, progressive measures that are not cost effective are likely to be resisted. There is evidence of that formula being applied. The government was content to legislate through LASPOA to bring 17-year-olds into line with the remand arrangements that applied to younger children, meaning that they could be remanded to non-secure local authority accommodation rather than automatically subject to custodial remand where bail was refused. In so doing, the Coalition contended that it was paying regard to the UN Convention on the Rights of the Child's requirement of a distinct treatment for all children under 18. Perhaps more relevantly, the measure carried limited financial risk since remands to local authority accommodation are, on average, cheaper than placements in the custodial estate. By contrast, the government contested the extension of the right to an appropriate adult to 17 -year-olds detained in the police station until the High Court determined that the Ministry of Justice's position was incompatible with Convention rights. Having lost that case, the Coalition has failed to address the anomaly whereby 17-year-olds refused police bail remain at the police station rather than being transferred to local authority accommodation (Bateman, 2013b). It is hard to avoid the conclusion that the difference resides in the costs associated with the latter measures.

Although the decline in child imprisonment has already delivered considerable savings, the government's Transforming Youth Custody agenda is predicated on reducing the per capita cost of incarceration to significantly below the current average of $£ 100,000$ per annum. Although ostensibly about putting 'education at the heart of detention' (Ministry of Justice, 2014b:3), the plans centre on the development of a network of 'secure colleges' that will replace young offender institutions, secure training centres and some secure children's home provision. Savings are to be achieved through economies of scale: the pilot secure college, to be opened in 2017, will hold 320 children, more than a quarter of the current custodial population, despite evidence of the benefits of 'small, local facilities with high staff to child ratios and positive relationships between staff and young people' (Standing Committee for Youth Justice, 2014:1). The new institution is to hold boys and girls, aged 12-17 years. Assuming a pro-rata distribution, one might anticipate that around 16 girls would be detained alongside more than 300 boys in this very large, rebranded, prison. 
Central to the Coalition's vision for criminal justice is payment by results ( $\mathrm{PbR}$ ) (Ministry of Justice, 2010). Having made precious little impact on levels of reoffending, the government is intent on transferring the financial risk to those commissioned to deliver services. Failure to meet targets, largely framed in terms of reduced recidivism, will incur financial penalty (HM Government, 2011). From the perspective of an austerity administration, the advantages of $\mathrm{PbR}$ are patent: reductions in re-offending will generate considerable economies for the state, but where such reductions are not achieved, the state will not pay service providers.

The logic of the financial mechanisms involved is questionable. If for example youth crime were to rise as a consequence of the recession (and reoffending showed a corresponding increase), $\mathrm{PbR}$ would dictate a reduction in resources to work with children in trouble, precisely at the point when a more considered approach would suggest that additional resources are required. More generally, $\mathrm{PbR}$ will generate pressures to lower the cost of providing a youth justice service to an absolute minimum as contractors strive to diminish potential financial loss. Targets will inevitably focus intervention on achieving short-term reductions in offending at the expense of longer-term developmental outcomes that prioritise children's wellbeing (National Association for Youth Justice, 2011).

$\mathrm{PbR}$ is more advanced in the adult justice sector although some youth justice pilots have been initiated and more are anticipated. The potential consequences highlight the fact that for children in conflict with the law, austerity informed policy is a double-edged sword.

Speculating about the future frequently proves to be a risky business and, with the 2015 general election on the horizon, the political environment may soon take on a different complexion. However, the continuity of youth justice policy between administrations described in this article suggests that a change of government may be less important - in terms of the prospects for child in trouble - than other factors. The current conjuncture is one fraught with ambiguity (Smith, 2014) and the future direction of youth justice policy is accordingly hard to read. The fault line around which tensions will play out is however likely to remain the same whichever party attains power. The dynamic of a continued requirement for financial stringency tends towards a further slimming down of the formal youth justice apparatus, heralding further falls in detected youth crime and custody alongside cuts to service provision and the deeper penetration of market mechanisms. A contradictory impetus is however associated with the neo-liberal need not to appear soft on youth crime (Garland, 2001) and, to the extent that this impulse gains greater momentum in the coming 
period, it has the potential to inaugurate a resurgence of penal punitivism, leading to a renewed cycle in which the boundaries of the youth justice system are again expanded. It is too early to tell which of these dynamics will proves stronger post-election, but, from the perspective of children in conflict with the law, much hangs on the outcome.

Tim Bateman

Reader in youth justice

University of Bedfordshire 


\section{References:}

Allen, R. 1991. Out of jail: the reduction in the use of penal custody for male juveniles $1981-1988$. Howard Journal for Penal Reform 30(1):30-52.

Allen, R. 2011. Last resort: exploring the reduction in child imprisonment 2008-11. London: Prison Reform Trust.

Bateman, T. 2012. Who pulled the plug? Towards an explanation of the fall in child imprisonment in England and Wales. Youth Justice 12(1): 36-52.

Bateman, T. 2013a. Children in conflict with the law: an overview of trends and developments - 2012. London: National Association for Youth Justice.

Bateman, T. 2013b. Detaining children at the police station: a failure to comply with legislation. London: National Association for Youth Justice.

Bateman, T. 2014 forthcoming. Youth crime and justice: statistical 'evidence', recent trends and responses. Goldson, B and Muncie, J (eds) Youth crime and justice. London: Sage

Centre for Social Justice. 2012. Rules of engagement: changing the heart of youth justice. London: Centre for Social Justice.

Cohen, S. 1985. Visions of social control: crime, punishment and classification. Cambridge: Policy press.

Creaney, S. and Smith, R. 2014. Youth justice back at the crossroads. Safer Communities 13(2): 83-87.

Criminal Justice Joint Inspectorates. 2012. Facing up to offending: use of restorative justice in the criminal justice system. London: Criminal Justice Joint Inspectorates.

Downes, D. and Morgan, R. 2012. Overtaking on the left? The politics of law and order in the 'Big Society. Maguire, M., Morgan, R. and Reiner, R. (eds) The Oxford handbook of criminology. $5^{\text {th }}$ edition. Oxford: Oxford University press: 182-205. 
Flanagan, R. 2008. The review of policing: final report. London: Home Office.

Garland, D. 2001 The culture of control: crime and social order in contemporary society. Oxford:

Oxford University press

Goldson, B. 2000. Wither diversion? Interventionism and the new youth justice. Goldson, B. (ed) The new youth justice. Lyme Regis: Russell House publishing: 35-57.

Goldson, B. 2002. New punitiveness: the politics of child incarceration, in Muncie, J, Hughes, G and McLaughlin, E (eds) Youth justice: critical readings. London: Sage: 386-399.

Goldson, B. 2010. The sleep of (criminological) reason: knowledge-policy rupture and New Labour's youth justice legacy. Criminology and Criminal Justice 10(1): 155-178.

Hart. D. 2012. Legal Aid Sentencing and Punishment of Offenders Act 2012: implications for children. London: National Association for Youth Justice.

Hart, D. 2014. Pre-court arrangements for children who offend. London: National Association for Youth Justice.

Home Office. 1997. No more excuses: a new approach to tackling youth crime in England and Wales. London: The Stationery Office.

Home Office. 2002. Final warning scheme: guidance for the police and youth offending teams. London: Home Office.

Home Office. 2007. National community safety plan 2008 -2011. London: Home Office.

Home Office. 2008. Youth crime action plan. London: Home Office.

HM Government. 2011. Open public services. Cm 8145. London: The Stationery Office.

Jacobson, J, Bhardwa, B, Gyateng, T, Hunter, G and Hough, M. 2010. Punishing disadvantage: a profile of children in custody. London: Prison Reform Trust. 
Leapman, B. 2008. Violent youth crime up a third. Daily Telegraph 20 January 2008.

Marlow, A. 2014. Thinking about the fall in crime. Safer Communities 13(2): 56-62.

McAra, L and McVie, S. 2007. Youth Justice? The impact of system contact on patterns of desistance from offending. European Journal of Criminology 4(3): 315-345.

McGuire, M. 2012. Criminal statistics and the construction of crime. McGuire, M, Morgan, R and Reiner, R (eds) The Oxford handbook of criminology. 5th edition. Oxford: Oxford University press: 206-244

Ministry of Justice. 2010. Breaking the Cycle: effective punishment, rehabilitation and sentencing of offenders. Cm 7972. London: The Stationery Office.

Ministry of Justice. 2013. Criminal Justice Statistics - quarterly update to December 2012: England and Wales. Supplementary tables. London: Ministry of Justice.

Ministry of Justice. 2014a. Youth custody report February 2014. London: Ministry of Justice.

Ministry of Justice. 2014b. Transforming Youth Custody: government response to the consultation. London: Ministry of Justice.

Ministry of Justice/ Youth Justice Board. 2014. Youth justice statistics $-2102 / 3$. Supplementary tables. London: Ministry of Justice.

Muncie, J. 2008. The 'punitive turn' in juvenile justice: cultures of control and rights compliance in Western Europe and the USA. Youth Justice 8(2): 107-121.

Nacro. 2008. Some facts about children and young people who offend - 2006. London: Nacro.

Nacro. 2010. The youth rehabilitation order. London: Nacro. 
National Association for Youth Justice. 2011. Payment by results and the youth justice system. London: National Association for Youth Justice.

Pitts, J. 1988. The politics of juvenile crime. London: Sage.

Pitts, J 2003. The new politics of youth crime: discipline or solidarity. Lyme Regis: Russell House publishing.

Pitts, J, and Bateman, T. 2010. New Labour and youth justice: what works or what's counted. Ayer, P. and Preston-Shoot, M. (eds) Children's services at the crossroads: a critical evaluation of contemporary policy for practice. Lyme Regis: Russell House: 52-63.

Ridge, T. 2013. 'We are All in This Together'? The hidden costs of poverty, recession and austerity policies on Britain's poorest children. Children and Society 27(5): 406-417.

Smith, R. 2003. Youth justice: ideas, policy and practice. Cullompton: Willan.

Smith, R. 2014. Youth justice: ideas, policy and practice. Third edition. Abingdon: Routledge.

Standing Committee for Youth Justice. 2013. SCYJ response to the Transforming Youth Custody consultation. London: SCYJ

Youth Justice Board. 2009. Annual report and accounts: 2008/09. London: Youth Justice Board. 